\title{
Wyndham Michael (Mike) Edmunds
}

\author{
31 July 1941-28 April 2015
}

Mike Edmunds was a major figure in groundwater science and a long-standing member of the Society for Libyan Studies. His international stature ensured that the Society could contribute to the building and the sharing of knowledge on the groundwater of Libya and its region.

Mike earned a BSc in Geology in 1964 and a $\mathrm{PhD}$ in Geochemistry in 1968 at the University of Liverpool. He focused on the genesis of garnet in polymetamorphic rocks. In 1966, he began a 35-year career at the British Geological Survey (BGS) where, to quote Willy Burgess of University College London, Mike became 'the father of hydro-geochemistry in the UK'. His research initially encompassed chemical processes in UK aquifers, the impacts of acid rain on shallow groundwater quality, and, as noted by Yousif Kharaka of the US Geological Survey, 'some of the earliest investigations of geothermal resources', particularly the chemistry of hot, dry-rock reservoirs.

Subsequent studies in the Sahara and Sahel sparked Mike's sustained interest in groundwater recharge and palaeohydrology in semi-arid regions. From the mid-1990s, he coordinated several major projects sponsored by the European Commission, including baseline groundwater quality and palaeohydrology of aquifers across Europe. He retired from an Individual Merit position at the BGS in 2001, but retained an appointment there as Honorary Research Associate.

Mike moved to Oxford University in 2002, taking up the position of Research Director of the Water Research Centre at the School of Geography and the Environment. He was a member of Christ Church. He continued to advance global groundwater science and management, notably in the UNESCO G-WADI programme. In 2004, he played a major role in the launch of the interdisciplinary MSc in Water Science, Policy and Management at Oxford. Exposure to Mike's exceptional scholarship and his very effective communication skills has resulted in many of his students achieving successful academic and practitioner careers.

In his late career, Mike was part of a network of 70 faculty and research staff in the Oxford Water Network. He contributed to innovative, interdisciplinary water science initiatives, including significant inputs to new programmes on Improving Water

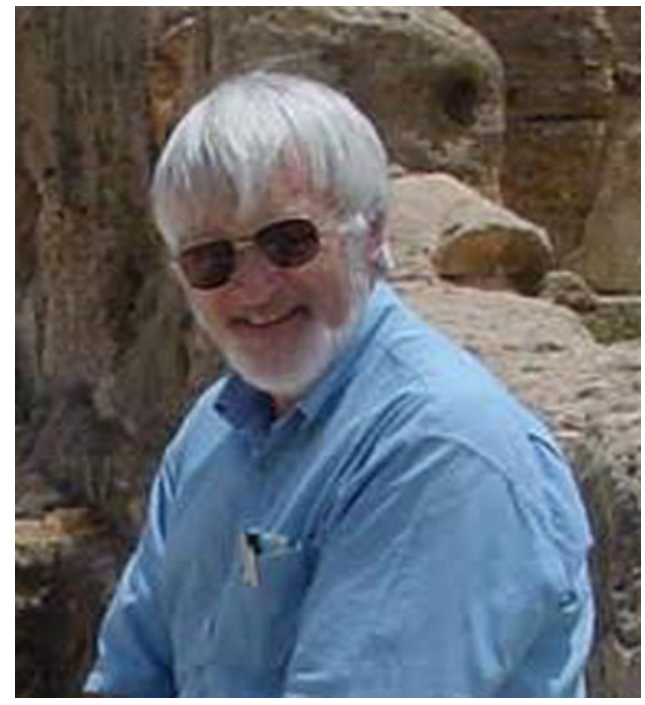

Mike Edmunds at Leptis Magna reflecting on Roman waste-water disposal. Photograph: Dr Rachael McDonnell.

Security for the Poor and on Groundwater and Poverty. Both programmes reflect Mike's enduring personal contributions to improving the lives of rural people in Africa and Asia. He contributed not only through his world-leading science, but also though his personal commitment, including over a decade as a trustee of Wells for India, which has transformed the lives of thousands of poor people in Rajasthan.

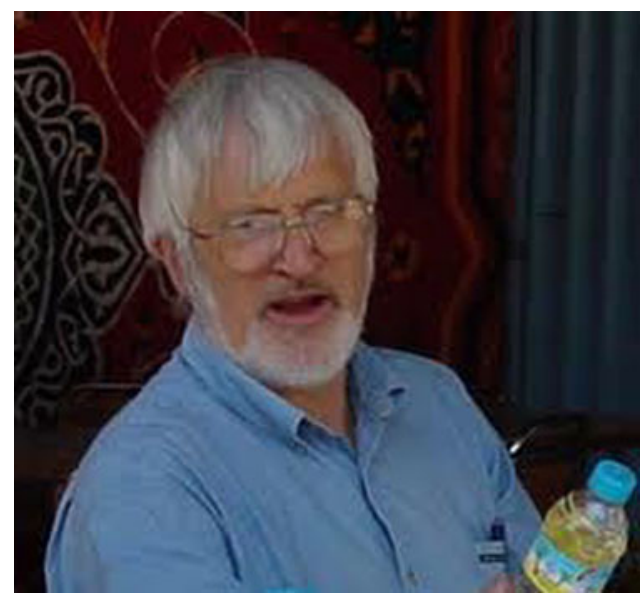

Mike Edmunds at Leptis Magna speaking with authority on water quality. Photograph: Dr Rachael McDonnell. 


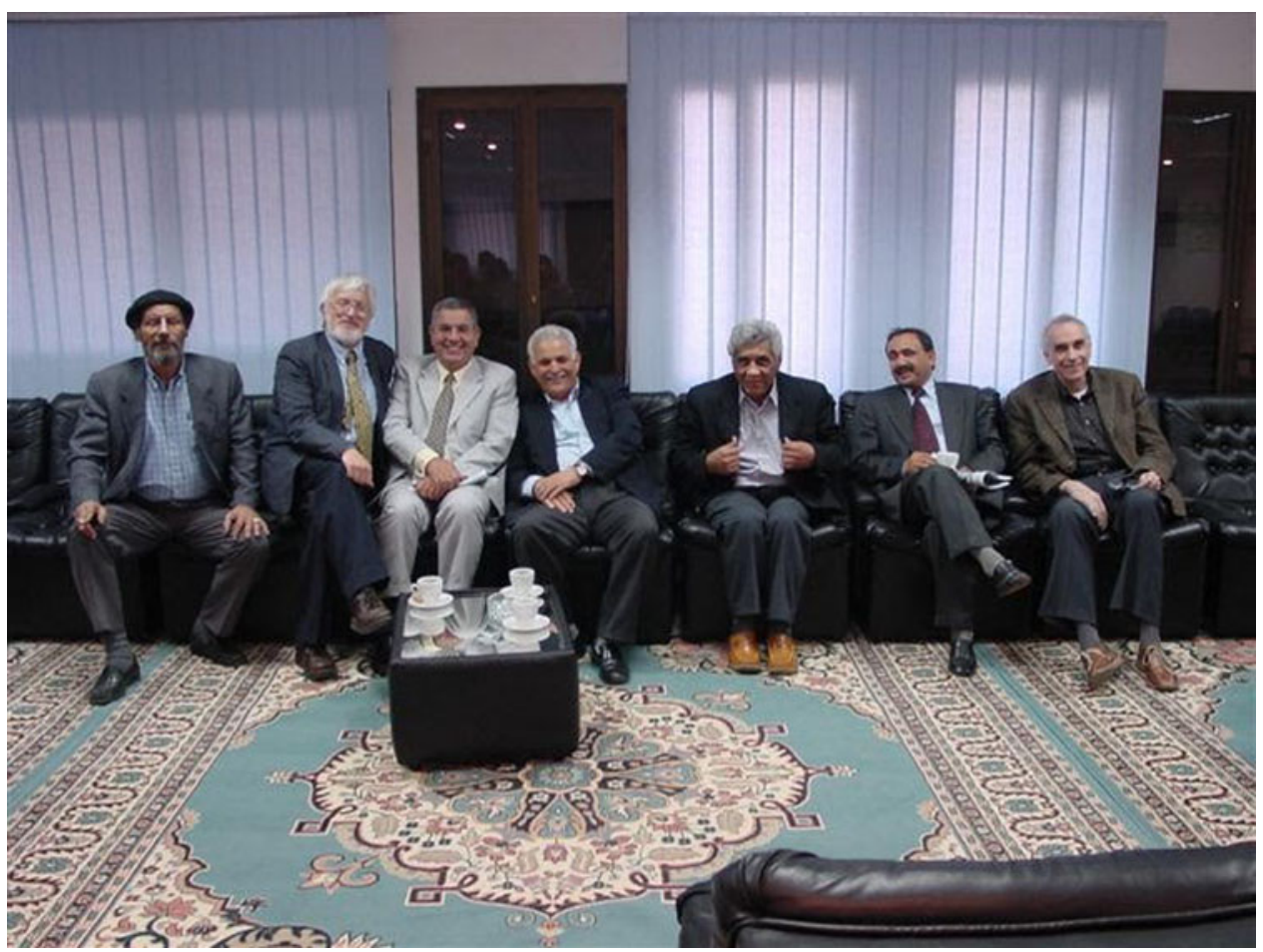

Mike Edmunds at a meeting in Tripoli in 2007 to discuss water science and Libyan water security. Left to right: Professor Saad Alghariai, Professor Mike Edmunds, Adam Kuwairi, Dr Omar Salem, Dr Abdulla Benseriti, Dr Mohamed Bakhbakhi, and Professor Tony Allan.

Mike's connection with the Society for Libyan Studies was long-standing and he was a member of the Council from 2005 to 2009. He worked closely with Ed Wright at the BGS in the 1960s on the nonrenewable groundwater resources of the Sahara. He established himself as an international authority on Saharan aquifers. His research with Ed Wright had major impacts through their bringing together the very substantial volume of groundwater records that were collected during the intense period of oil exploration in Libya in the 1950s and 1960s. Ed died over 25 years ago. Together they were the leading international authorities on Libyan and Saharan aquifers.

In the 2003-2005 period, Libyan relations with the international community improved. Mike was in a strong position to extend advice on research and higher education on water science and governance. He drafted some proposals for integrated inputs by Oxford and London University staff to universities and other institutions in the Libyan water sector. Unfortunately, oil prices started to rise and the Libyan leadership lost interest in the initiatives.
Mike gained and kept everyone's deep respect. It is hard to imagine the future without being able to contact him to access his unique expertise and the amiable conversation that would always take place.

Salem El Maiar conveyed this message from the scientists and professionals with whom Mike had worked in Libya:

When Mike's Libyan friends heard of his death, they were very saddened by the news. They recognised the great loss to the Libyan water sector and its science. They have recognised the great importance of his research on the aquifers of Libya and the basins that feed the man-made river project. They were honoured to have worked with him. They used his publications and analysis to underpin the modelling of depth, distribution, and the production of wells. Above all they appreciated Mike's respect for Libya and its scientists.

Mike Edmunds died on 28 April 2015. With his wife Kathy, he had four children and there are six grandchildren.

\section{School of Oriental and African Studies}

